\title{
TEACHING READING BY USING INQUIRY BASED LEARNING APPROACH TO THE FIRST SEMESTER OF ENGLISH EDUCATION PROGRAM
}

\author{
Syaprizal $^{1}$ \\ STKIP PGRI Lubuklinggau \\ syaprizal_mpd@yahoo.com ${ }^{1}$
}

Submit, 08-11-2017 Accepted, 30-12-2017 Publish, 30-12-2017

\begin{abstract}
The objective of this study was to find out whether or not it was significantly effective to use Inquiry Based Learning in teaching reading to first semester of English Education Program . In this study, the writer proposed two hypotheses. They were null hypothesis (Ho) and alternative hypothesis (Ha). The method applied was pre-experimental with one group pre-test posttest design. The population of this study was all of first semester of English Education Program which consisted of 45 students. The sample was taken through cluster random sampling. Which consisted of 20 students. The data were collected by means of test consisting 20 items of multiple choices. The data obtained were analyzed through three techniques: 1) Individual Score, and 2) Matched t-test. The results of this study shows that the students' mean score in the pre-test was 60.13 and those in the post-test was 75.25. The result of matched t-test was 5.25, which was higher than t-table value (1.725) of 20 with $95 \%$ significant level for one tailedtest. Therefore, the null hypothesis (Ho) was rejected and the alternative hypothesis (Ha) was accepted. It means that it was significantly effective to use Based Learning Approach in teaching reading to first semester of English Education Program .
\end{abstract}

Keyword: teaching reading, using inquiry based learning approach.

\section{INTRODUCTION}

Language is a fundamental part of human being (Haliwel, 1992:11). Language is an important part of humans in communicating to each other. Through language, people learn how to "mean things" and how to share all of those meanings with others. The term language refers to set of intricate rules which function as a medium of human style of communication, (Siahaan, 2008:40). In simple word, language is used by people to communicate and share 
information all about their life. Reading and Listening are called receptive skills because when we listen and read something we receive the language, understand it and decode the meaning. Speaking and writing are called productive skills because we use the language to produce a message through speech or written text. Productive skills is the term for speaking and writing, skills where students actually have to produce language themselves (Harmer, $2007: 65$ ).

Reading is the act of constructing meaning while transacting with text. It means that when people use information stored in schemata to understand and interact with the world around people, so do people use this knowledge to make sense of print. Since the reader has not said anything about the reader's "getting" meaning. From the author, the page, or anywhere else. It means that by reading people will get the information which is stated in a text or a book.

As a matter of fact, many books or journals are written in English, therefore by mastering English reading people also can interact with the world. Reading is a physic and mental activity to reveal the meaning of the written texts, while in that activity there is a process of knowing letters. According to Saleh (1997:3), English is considered as one of the vehicles to actualize the philosophy of life long education by progressive high school graduates.

The researcher believed, the readers literally make meaning from the interaction between prior knowledge and previous experience (what they already known) from the information available in text, from the "stance" or position they elect to take in relationship to the text and from immediate, remembered, or shared social interaction and communication of this nation of "transaction" (Ruddel, 2005:30).In other words, reading is the process where people try to combine the knowledge that they had before with their present knowledge then they try to comprehend and understand what they read.

Therefore, the students had many problems with the meaning, the use of tenses, and aspects of reading text such as vocabulary. Finally, the students felt low motivation in learning, they did not interested in teachers' strategies, techniques and approaches in teaching reading. The students were lack of motivation and exposure in reading comprehension. It can be stated that students did not have motivation to expose their reading skill especially in comprehending text.

Based on the problems above, the researcher intends to conduct a research to prove the effectiveness of using Inquiry Based Learning Approach in teaching Reading. Therefore, the research entitled: "Using Inquiry Based Learning Approach in teaching reading to the first semester of English Education Program". 


\section{LITERATURE REVIEW}

\section{Reading Comprehension}

Reading comprehension is the basic purpose for reading, underlying and supporting most other purposes for reading and more complex than commonly assumed. There are some reading strategies used by good readers, skills essential to students' academic success: pre-reading, initial reading, getting the main ideas section, guessing meaning from context, re-reading, and post-reading exercise. Reading comprehension is a constructive, interactive process involving three factors the reader, the text, and the content in which the text is read (Gunning 1992:188).

Catherine (2002:13) states that reading comprehension has focused on specific factor (e.g. Vocabulary knowledge) without specifying either that the effect of that factor reflects a relationship among reader, text, and activity or that the factor may change from pre-reading to reading to post-reading.

Reading is the act of constructing meaning while transacting with text. Just as we use information stored in schemata to understand and interact with the world around us, so do we use this knowledge to make sense of print. Notice that I have not said anything about the reader's "getting" meaning. From the author, the page, or anywhere else. I believed, as do others that readers literally make meaning from the interaction between prior knowledge and previous experience (what they already known) from the information available in text, that can be easy to be remembered or shared in social interaction and communication of this nation of "transaction" (Ruddel, 2005:30).

\section{The Concept of Inquiry Based Learning Approach}

According to Amri and Ahmadi(2010:87),Inquiry-based Learning Approach is a student-centered and teacher-guided instructional approach that engages students in investigating real world questions. Inquiry-Based instruction complements traditional instruction by providing a vehicle for extending and applying the learning of students in a way that connects with their interests within a broader thematic framework. Students acquire and analyze information, develop and support propositions, provide solutions, and design technology and arts products that demonstrate their thinking and make their learning visible.

In addition, Sanjaya (2006:196) states that Inquiry Based Learning Approach is an approach that consists of some activities of learning that focus on the process of how to think analytically to search and find the answers of the problems in reading. The thinking process is usually done through questions and answers between the teacher and the students. It means that this approach emphasizes the students to find the answers by themselves. Therefore, the 
students are required to be active in finding the answers of reading text, especially, descriptive text.

Moreover, Cooper and Prescott (1989:3) state that research shows that the amount of student learning that occurs in a classroom is directly proportional to the quality and quantity of student involvement in the educational program. However research studies indicate that teachers typically dominate classroom conversation, consuming nearly $70 \%$ of classroom time.

Finally, Banchi and Bell (2008:22)state that clearly outlines four levels of inquiry. The progression seen from level one through four provides an excellent guide for how to scaffold inquiry learning skills for students.

Level 1 : Confirmation Inquiry, the teacher has taught a particular science theme or topic. One student then develop questions and a procedure that guides students through an activity

Level 2 : Structured Inquiry, the teacher provides with question and procedure. Students are to formulate explanations of their findings through evaluating and analyzing the data that collect.

Level 3 : Guided Inquiry, the teacher only provides the research question for students. The students are responsible for designing and following their own procedures to test that question and then communicate their result and findings.

Level 4 : Open Inquiry, students formulate their own research question, design and follow through with a developed procedure, and communicate their findings and results.

\section{Students' Reading Achievement}

An achievement is a measurement of how much of a language has learned with reference to a particular course of study or programme of instruction (Trumble, 2001:11).

Students' reading achievement means the students' difference score that is related to their particular course of instruction. For example, an achievement reading comprehension test based on particular set of descriptive text question. The test helps the teacher to judge the success of his or her teaching and to identify the weakness of his or her students.

\section{The Steps of Teaching Reading by Using Inquiry Based Learning Approach}

Based on procedures that proposed by Wilherm(2010:11), Inquiry Based Learning Approach through the following steps:

1. Teacher activates the students' prior knowledge. The teacher asks to the students about their opinions that relates to the topic of the reading text. 
2. The teacher divides the students into groups (each group consist of five students). The teacher gives the topic of the reading text.

3. Teacher invited the students to appoint their own group leader

4. The teacher establishes a general topic or inquiry of the topic of Descriptive text.

5. The teacher provides the students about the books/reading text which related to the descriptive text. After that the students do their own inquires.

6. The teacher helps the students to find the answers of the text.

7. The teacher asks students a lot of questions to help them refine their thinking.

8. The teacher evaluates result and process of study and reviewing the questions and answers that are stated on the text.

\section{The Advantages of Inquiry Based Learning}

According Dewey (2012:52), there are several advantages to an Inquiry Based Learning approach to learning. An Inquiry based approach is:

1. Qualitative: It can be used in teaching reading content and suitable for the groups.

2. Flexible for students: It motivates students to be more creative by giving them more freedom, time, and for discovery.

3. Highly motivating: As students become engaged in the question forming process, they take ownership of their learning.

4. Connected to the real world: It works to prepare students for real-life situations. It reinforces multiple skills and allows students to build the confidence to know where and how to get wanted information.

\section{Research Hypotheses}

According to Arikunto (2006:17), hypotheses is the temporary answer of study problem, till realized through the data has collected. Based on the problem and the objective above, the research hypothesis in this study is "is it significantly effective to students reading achievement by using inquiry based learning approach to the the first semester of English Education Program". In this study there are two hypotheses. The null hypothesis (Ho) and the alternative hypothesis (Ha).

1. The null hypothesis (Ho) : stated that it is not significantly effective to teach reading by using inquiry based learning approach to the the first semester of English Education Program. 
2. The alternative hypothesis $(\mathrm{Ha})$ : stated that it is significantly effective to teach reading by using inquiry based learning approach to the first semester of English Education Program

\section{RESEARCH METHOD \\ Research Design}

In this research, the writer used a pre-experimental with one-group pretest and post-test design. According to Fraenkel and Wallen (1993:236),preexperimental method is a method that has one group pre-test and post-test design, a single group is measured or observed not only after being expose to a treatment of some sort, but also before.

\section{Population and Sample}

According to Arikunto (2010:173), population is the entire subject in the research. The population is represented by test norms or the group of examines represented by the norms is referred to as the reference population. Population is the entire set of individuals, items, or scores from which a sample is drawn. In this research, the population is all the the first semester of English Education Program.

According to Arikunto (2010:74), sample is a part of representative of population investigated. From the explanation above, the writer will take one class as the sample of this investigation. The writer will use the purposive sampling.

\section{Techniques for Collecting the Data}

In this research the instrument was reading comprehension test. The reading comprehension test in multiple choice tests with four choice. The total of items of instruments were 25 questions. In collecting the data, writer give the instrument to the students to allow the students assess the effects of experimentation and to know how the students' achievement about what they have learned.

\section{Techniques for Analyzing the Data Matched t-test}

The results of the test are analyzed by using matched t-test. Matched t-test is comparison of the result of students' mean score in pretest and the students' mean score in the post test.

Formula of the matched $t_{\text {test }}$ is as follow:

$$
\mathrm{t}_{-\mathrm{obt}}=\frac{\overline{\mathrm{R}_{\mathrm{z}}}-\overline{\mathrm{N}_{1}}}{\mathrm{~s}_{\mathrm{D}}}
$$


Where:

$\mathrm{t}^{-{ }_{\text {obt }}}=\mathrm{t}$ - obtained.

$\overline{\mathrm{X}}_{1} \quad=$ the students' means score in the pre-test.

$\overline{\mathrm{X}}_{2} \quad=$ the students' means score in the post-test.

$s_{\bar{D}} \quad=$ Standard error of difference. (Hatch and Farhady, 1982:116)

\section{Accountability of the Research Validity}

Validity is the essential idea to consider when preparing or selecting an instrument for use. The validity of the test material was using content validity. Wallen and Frankel (1990:47) state that content validity is the degree to which in instrument measures an intended hypothetical psychological construct, or no observable trait. In order to know if the contents of the test items given are appropriate, the writer checked material in curriculum. Before give the treatment to students, the students were given the tryout of instrument.

\section{Reliability}

Reliability is a measure of the degrre to which the test givens consistent result. In this research there are twenty five reading questions that are measured to get their reliability levels. According to Fraenkel and Wallen, (1990: 136) stated that the test is considered realiable when the reliability coefficient of the tests should be at least 0.70 and preferable higher. In estimating the reliability coefficient, the writer applied Kuder Richardson 21 (KR-21), it was found that 0,73. It means the reading test instrument was reliable since it was higher than 0.70 .

\section{Normality}

The investigation of the interval consistency normal is estimated by Arikunto (2005:161). The following is the normality distribution

Formula (chi square ):

$\mathrm{X}^{2}=\sum \frac{\left(O_{i}-E_{i}\right)^{2}}{E_{1}}$

Where:

$\mathrm{Oi}=$ The observation freguency

$\mathrm{Ei}=$ The expertiso freguency

\section{FINDING}

In this study, the writer found that Inquiry Based Learning Approach is effective to be used in teaching reading comprehension to the first semester of English Education Program. It can increase the students' more active in the class 
room, and interested in learning reading comprehension using Inquiry Based Learning Approach. The findings in this study included the students' score in the pre-test, the students' score in the post-test, and the result of matched-test calculation between the students score in pre-test and those in the post-test.

The writer found that $t_{\text {obtained }}$ was 4.003 which exceeded 1.701 as its critical value. It means that the alternative hypothesis (Ha) was accepted and null hypothesis (Ho) was rejected. In other word, it was effective to use Inquiry Based Learning Approach in teaching reading to the first semester of English Education Program. It means indirectly the Inquiry Based Learning Approach was effective to be used. The comparison between the students' pre-test and post-test scores is shown in the following chart.

\section{The Students' Scores in the Pre-test}

Before the writer calculated the experiment, she gave the student pre-test then took their scores. After the scores had been tabulated, the writer found that the highest score was 80 , reached by 1 students, and the lowest score was 45 , Reached by 1 student. In addition the averages score was 63 .

\section{The Students' Scores in the Post-test}

Before giving the post-test, the writer taught reading comprehension using guided reading procedure Inquiry Based Learning Approach. In this case, the test items in the post- test were the same as those in pre-test. In the post-test, the highest score was 100 reached by 1 student, and the lowest score was 55 reached by 2 students. The averages score was 75.25 .

\section{Data Normality}

In the pre-Test

Based on the data of the students' scores in the pre-test, the writer found out that $\mathrm{x}^{2}$ obtained $=10.31$ with degree of freedom $(\mathrm{df})=5(6-1)$. Since level is $95 \%(0.05)$, and the $x^{2}$ table $=11.070$ with the data was normal, because $\mathrm{x}^{2}$ obtained was higher than $\mathrm{x}^{2}$ table.

\section{In the post -test}

Based on the data of the students' scores in the post-test, the writer found out that $\mathrm{x}^{2}$ obtained $=12.8376$ with degree of freedom $(\mathrm{df})=5(6-1)$. Since level is $95 \%(0.05)$, and the $\mathrm{x}^{2}$ table $=11.070$ with the data was normal, because $\mathrm{x}^{2}$ obtained was higher than $\mathrm{x}^{2}$ table. 


\section{The Calculation of the Matched t-test}

Based on the students' score obtained both in the pre-test and in the posttest, the writer calculated the matched t-test to find out whether or not guided reading procedure Inquiry Based Learning Approach was significantly effective to teach reading comprehension to the first semester of English Education Program.

By using the students' score in the pre- test and the post-test, the writer found that the result of matched t-test for the whole class was 4.003. Meanwhile, the critical value of $95 \%$ with df 19 (20-1) significance level was 1.701 . It means that the $t_{\text {obtained }}$ (4.003) exceeded the $t$-critical value (1.701). It means that the alternative hypothesis (Ha) which was stated that guided reading procedure Inquiry Based Learning Approach was effective in teaching reading comprehension to the first semester of English Education Program was accepted and the null hypothesis (Ho) was rejected.

\section{DISCUSSION}

After getting the data from test, the writer interpreted the result of the data analysis. As described above, the writer found that after teaching reading by using guided reading procedure Inquiry Based Learning Approach, the students' achievement increased. It can be seen from the difference between the students' score in the pre-test and that in the post-test. Some data obtained include: a) the students' average score was $63, \mathrm{~b}$ ) the highest score 100 , which was achieved by 1 student, and c) the students lowest score was 55 achieved by 1 student. It can be interpreted that their ability in reading comprehension was failed category.

The explanation above repeated that the students were not very good in their knowledge; it was because the students could not comprehend reading text well. They could not differ between information based on the text and that based on their knowledge. That is why the student felt difficulties to answer the question and consequently they were classified as failed category.

On the other hand, in the post-test, their average score increased to be 75.25 , with the highest score was 100 achieved by 1 students and the lowest was 55 achieved by 1 students. Their average ability was in passed category. It means that after treatment, the students were better in reading comprehension and in answering the questions.

Therefore, the writer felt necessary to give treatment for the students. Treatment was done to the experiment class in order to improve the students' achievement on certain area. In the treatment the writer used Guided Reading Procedure Inquiry Based Learning Approach to teach reading comprehension. That the thing that is the most basically in teaching and learning process in the students being active. The students being active in learning process will get the high interaction between teacher and students. Learning can be successful if all of 
the students or parts of the students mixed up each other in active manner in learning process. The activities that have done the students for learning will be influence the student's memory on the lesson that have been given by the teacher.

In additional, the result of matched $\mathrm{t}$-test calculation shows that the $\mathrm{t}$-obtained was higher than $t$-table. The $t$-obtained was 4.003 , while the $t$-table was 1.701 . It means that null hypothesis (Ho) was rejected and the alternative hypothesis (Ha) was accepted. Inquiry Based Learning Approach was effective to be used in teaching reading comprehension to the first semester of English Education Program.

In conclusion, it's clear that Guided Reading Procedure Inquiry Based Learning Approach has advantages in learning process. By using Guided Reading Procedure Inquiry Based Learning Approach could increase students' skill in comprehending reading text, the students have high motivation and can be active in learning process. Motivation is give reason, incentive, enthusiasm, or interest that causes a specific action or certain behavior, and for the English teachers, this strategy can be used in learning process to develop students' achievement in reading comprehension.

\section{CONCLUSION}

Based on the finding and discussion, the writer concluded that it was significantly effective to use Inquiry Based Learning Approach in teaching reading to the first semester of English Education Program. There was improvement of the average score or the average ability from the pre-test (63) to the post-test (75.25). This was showed in the average score post-test was higher than average score in the pre-test, and their average ability changed from failed based on the minimum mastery criteria to be mastered. The result of the t-obtained was 4.003 , it was higher than 1.701 as critical value for one tailed test. So, the null hypothesis (Ho) was rejected and automatically the alternative hypothesis (Ha) was accepted. In other words, it was effective to use Inquiry Based Learning Approach in teaching reading to the first semester of English Education Program. In conclusion the experiment done by the writer was successful, because there was an improvement on the result of the students' scores in the pre-test and the post-test. 


\section{REFERENCES}

Arikunto, S. (2010). Prosedur Penelitian Suatu Pendekatan Praktik. Jakarta: Rineka Cipta.

Amri, S. \& Ahmadi, KS. (2010). Proses Pembelajaran Kreatif dan Inovatif Dalam Kelas. Jakarta: PT.Prestasi Pustaka Raya.

Banchi, H., \& Bell, R.( 2008). Teaching Reading by Using Inquiry Based Learning Approach. [Online]. http//www.google.warmingupforreadingpdf.com. Accessed on February 24, 2014.

Catherine, S. C. (2002). Reading for Understanding. Pittsburgh ; Rand Reading Study Group.

Cooper, L., \& Prescot, T. (1989). The Reading Priority in English. New York; NY: McGraw-Hill, Inc

John Dewey. (2012). Inquiry Based Learning Approaches to Learning. [Online]. http://www.glencoe.com/sec/teachingtoday/subject/inquirybased.phtml.

Fraenkel, J. R., \& Wallen, N. E. (1990). Education Research: A Guide to the Process. New York, NY: McGraw-Hill, Inc. (1993). How to Design and Evaluate Research in Education. New York, NY: McGraw-Hill, Inc.

Gunning, G. T. (1992). Reading Comprehension Boosters. United State Of America ; John Wiley \& Sonic, Inc. All rights reserved.

Haliwel, S. (1992). Longman Handbooks For Language Teachers Teaching English In The Primary Classroom. New York: Longman

Harmer, J. (2007). The Practice of English Language Teaching. Cambridge, UK: longman.

Hatch, E., \& Farhady, H. (1982). Research Design and Statistics For Applied Linguistics. London: Newbury House Publisher. INC.

Ruddell, R. M. (2005). Teaching Content Reading and Writing. Danvers, MA: John Wiley \& sons, Inc.

Saleh, Y. (1997). Approaches of Teaching English as A Foreign Language in the Indonesian Context Book 1. Palembang: Faculty of Teacher Training and Education, Sriwijaya University. (1997). Methodology of TEFL in Indonesian Context. Faculty of Teacher Training and Education Sriwijaya University, Palembang.

Sanjaya, W. (2006). Strategi Pembelajaran Berorientasi Standar Proses Pendidikan. Jakarta: Kencana Prenada Media.

Siahaan, S. (2008). Issues in Linguistics. Yogyakarta: Graha Ilmu

Trumble, J. (2001). The Great Dictionary of English: London: Longman,Ltd

Wilherm. (2010). Criteria For a Successful Inquiry. Online http://Amazone Components $2 . h t m l$ 